Tersedia Online di http://journal2.um.ac.id/index.php/jmsp/

ISSN Online : 2541-4429

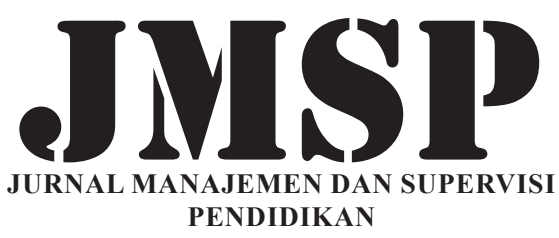

PENDIDIKAN

\title{
GAYA KEPEMIMPINAN KEPALA TAMAN KANAK-KANAK
}

\author{
Novi Cahya Dewi ${ }^{1}$; Aslan²; Muhammad Suhardi ${ }^{3}$ \\ 1,2Institut Agama Islam Sultan Muhammad Syafiuddin Sambas \\ Jl. Sejangkung Kawasan Pendidikan No.126 Sebayan Kecamatan Sambas Kabupaten Sambas \\ Kalimantan Barat Indonesia \\ ${ }^{3}$ Universitas Pendidikan Mandalika \\ Jl. Pemuda No. 59A Dasan Agung Baru Mataram Indonesia \\ aslanmarani88@yahoo.com
}

\begin{abstract}
This research was conducted in the Yogyakarta Kindergartens State Kindergarten which aims to find out, among others, First, an overview of the leadership style of the Yogyakarta Kindergarten State Schools, Second, the factors that lead to the subject's leadership, Third, how to develop the subject's leadership style. Based on the results of research conducted by interview and observation methods, the leadership style obtained at the Headmaster of Yogyakarta State Kindergarten is the executive leadership style. Where have the characteristics of giving high spirits to subordinates with high moral example, maintaining others in accordance with their respective characteristics and view people as coworkers and more importantly is able to establish good relationships with new people and view conflict as a matter of reasonable.
\end{abstract}

Keywords: leadership style, principal, kindergarten

\begin{abstract}
Abstrak: Penelitian ini dilakukan di TK Negeri Pembina Yogyakarta yang bertujuan untuk mengetahui, diantaranya., Pertama, gambaran gaya kepemimpinan kepala sekolah TK Negeri Pembina Yogyakarta, Kedua, faktor-faktor yang menyebabkan Kepemimpinan subjek, Ketiga, cara mengembangkan gaya kepemimpinan subjek. Berdasarkan hasil penelitian yang dilakukan dengan metode wawancara dan observasi, maka diperoleh gaya kepemimpinan pada kepala sekolah TK Negeri Pembina Yogyakarta adalah gaya kepemimpinan executive. Dimana memiliki ciri-ciri memberikan semangat yang tinggi kepada bawahan dengan contoh moral yang tinggi, mempertahankan orang lain sesuai dengan sifat masing-masing dan memandang orang sebagai teman kerja dan yang lebih penting adalah dapat menjalin hubungan yang baik dengan orang baru dan memandang konflik sebagai hal yang wajar.
\end{abstract}

Kata Kunci: gaya kepemimpinan, kepala sekolah, TK

Sejak manusia dilahirkan hingga sepanjang hidupnya, manusia tidak lepas dari suatu kebutuhan yaitu untuk mendapatkan pendidikan. Pendidikan perlu dimulai sejak dini, terlebih untuk mengejar ketertinggalan kita memasuki era globalisasi, terutama masalah kualitas sumber daya manusia. Melalui pendidikan usia dini dapat di bangun pilar-pilar sumber daya manusia yang mampu bersaing dengan sumber daya manusia dari negara lain. Pendidikan Taman Kanak- Kanak membantu membentuk generasi muda yang handal. Taman Kanak-Kanak merupakan bentuk pendidikan prasekolah yang menyediakan program pendidikan dini untuk mempersiapkan anak memasuki pendidikan Sekolah Dasar. Dewasa ini, masyarakat sering memandang bahwa kualitas sumber daya manusia perlu ditingkatkan, dan di Indonesia pendidikan merupakan salah satu faktor yang harus didukung karena kemajuan suatu bangsa tidak lepas dari kemajuan pendidikannya. Mutu pendidikan akan tercapai apabila komponen yang terdapat dalam meningkatkan mutu pendidikan memenuhi syarat tertentu. Komponen yang berperan dalam peningkatan mutu pendidikan salah satunya adalah tenaga pendidik yang bermutu yaitu yang mampu menjawab tantangan-tantangan dengan cepat dan bertanggung jawab. 
Tenaga pendidik mempunyai peran yang sangat strategis dalam pembentukan pengetahuan, ketrampilan, dan karakter peserta didik, karena itu tenaga pendidik yang profesional akan melaksanakan tugasnya secara profesional sehingga menghasilkan siswa yang lebih bermutu. Untuk meningkatkan kualitas dan efektivitas mengajar guru, banyak faktor yang mempengaruhinya, diantaranya adalah kepemimpinan kepala sekolah, karena kepala sekolah merupakan orang yang berperan penting dalam mengatur aktivitas proses belajar mengajar dan kepala sekolah juga bertanggung jawab langsung terhadap pelaksanaan segala jenis dan bentuk peraturan atau tata tertib yang harus dilaksanakan baik oleh guru maupun peserta didik. TK Negeri Pembina Yogyakarta adalah termasuk TK Negeri yang memiliki akreditasi sangat baik, karena TK Negeri Pembina Yogyakarta ini sudah menyandang akreditasi"A" dan setiap tahunnya peserta didik TK Negeri Pembina memiliki peningkatan dan prestasi yang gemilang untuk tingkat Nasional. Oleh karena itu bagaimana cara kepala sekolah dalam berinteraksi dengan bawahan sangat mempengaruhi akan berhasil atau tidaknya sekolah yang dipimpinnya, serta turut mempengaruhi keteladanan guru dan siswa dalam proses belajar mengajar. Di Amerika Serikat, seperti ditegaskan Papalia dan Olds, lembaga pendidikan prasekolah yang dianggap baik adalah yang dapat merangsang perkembangan anak dalam seluruh aspek, baik jasmaniah, sosial, emosional, maupun intelektual, melalui interaksi aktif dengan para guru, anak-anak yang lain, dan juga melalui bahan-bahan belajar yang telah dipilih. Secara tepat dikatakan (Goals ofpreschool education vary according to the values of the culture. In the United States, a good preschool is concidered to be one that stimulates children'sdevelopment in all domain- physical, social, emotional, and cognitive-throughactive interaction with teachers, other children, and carefully chosen materials). (Papalia dkk, 1998:213).

Untuk menjadikan lembaga pendidikan (pengasuhan) anak usia dini memiliki ciri-ciri positif seperti yang disebutkan Papalia dan Olds tersebut, tentu memerlukan pengelolaan yang baik, sebab dengan pengelolaan yang cermat merupakan hal esensial untuk mencapai keberhasilan program pendidikan anak usia dini. "Thoughful planning and administration are essential to the succes of early childhood programs". (Decenzo D.A and Robbins, S.P, 1999:5). Peranan kepala sekolah dalam rangka mutu pendidikan sangat penting karena dapat mempengaruhi berhasil dan tidaknya mutu pendidikan itu sendiri. Kepala sekolah sebagai tulang punggung mutu pendidikan dituntut untuk bertindak sebagai pembangkit semangat, mendorong, merintis dan memantapkan sertasekaligus sebagai administrator.

Dengan demikian, dari paparan diatas, maka kajian ini untuk melihat lebih jauh tentang; Pertama, bagaimana gambaran gaya kepemimpinan kepala TK Negeri Pembina Yogyakarta?. Kedua, apa faktorfaktor yang menyebabkan gaya kepemimpinan subjek?. Ketiga, Bagaimana cara mengembangkan gaya kepemimpinan subjek?

\section{METODE}

Penelitian ini menggunakan penelitian kualitatif dengan metode deskriptif dimana suatu bentuk penelitian yang ditunjukkan untuk mendeskripsikan atau menggambarkan fenomena-fenomena yang ada baik fenomena alamiyah maupun rekayasa manusia. (Moleong, 2008:17). Lokasi penelitian jl. Glagahsari, Umbulharjo 3/369 Celeban Yogyakarta, lokasi TK Negeri Pembina tidak jauh dari pemukiman warga dan terletak ditengah permukiman warga. TK ini memiliki tempat yang strategis dimana luas tanah 1798m2 dan luas bangunan 1043m2 dengan kapasitas jumlah murid yang memadai. TK Negeri Pembina ini mendidik anak usia dini dari usia 4 tahun sampai dengan usia 6 tahun. Objek penelitian ini adalah kepala dan guru TK Negeri Pembina, adapun teknik pengumpulan data dalam penelitian yang penulis gunakan adalah teknik observasi, wawancara dan dokumentasi, adapun yang dimaksud teknik observasi adalah metode pengumpulan data melalui pengamatan langsung atau peninjauan secara cermat dan langsung. (Sugiyono, 2007:2). Penelitian ini penulis menggunakan observasi non-partisipan yaitu penulis tidak terlibat secara langsung melainkan hanya sebagai pengamat independen. (Sugiyono, 2007:2). Jadi dalam teknik observasi non-partisipan ini penulis datang di tempat yang diamati akan tetapi hanya mengamati kegiatan dan tidak ikut terlibat dalam kegiatan tersebut.

Jenis wawancara yang digunakan dalam penulisan ini adalah wawancara terstruktur yakni dalam melakukan wawancara, pengumpulan data telah menyiapkan intrumen penelitian berupa pertanyaan- 
pertanyaan tertulis. (Sugiyono, 2007:17). Metode ini digunakan penulis untuk mewawancarai kepala sekolah TK Negeri pembina untuk mengetahui hal-hal yang terkait tentang gaya kepemimpinan sehingga mudah memperoleh informasi untuk melengkapi data penelitian. Sementara teknik dokumentasi dalam penelitian ini adalah mencari data mengenai hal-hal berupa catatan, transkip, buku-buku, surat kabar, majalah dan sebagainya. (Arikunto, 2010:19). Metode dokumentasi digunakan sebagai metode pendukung dalam penelitian ini.

Adapun tahap analisis data dalam penelitian ini adalah reduksi data, penyajian data dan verifikasi (penarikan kesimpulan). Reduksi data berfungsi sebagai merangkum, memilih hal-hal yang pokok, memfokuskan pada hal-hal yang penting, dicari tema dan polanya. Dengan demikian data yang telah di reduksi akan memberikan gambaran yang lebih jelas dan mempermudah peneliti untuk melakukan pengumpulan data selanjutnya dan mencarinya bila diperlukan. (Sugiyono, 2007:92). Dalam penelitian kualitatif penyajian data bisa dilakukan dalam bentuk uraian singkat, bagan, hubungan antar kategori dan sejenisnya. (Sugiyono, 2007:95). Sedangkan verifikasi atau penarikan kesimpulan yang dimaksudkan dalam penelitian ini adalah sebagai penaraikan makna dari data yang tampil dengan melibatkan pemahaman sipeneliti. (Adnan dan Mujahidin, 2004:138)

Teknik pemeriksaan keabsahan data yang digunakan dala penelitian ini adalah triangulasi data dan member-check. (Sutama, 2010:233). Trianggulasi sumber dilakukan dengan cara membandingkan dan mengecek kembali informasi dari informan satu dengan informan yang lain, trianggulasi metode dilakukan dengan memanfaatkan penggunaan beberapa metode berbeda untuk memperoleh informasi. Sedangkan member-check dilakukan pada subjek wawancara yaitu pada saat wawancara dan melalui rangkuman hasil yang telah dibuat penulis.

\section{HASIL DAN PEMBAHASAN}

\section{Kepemimpinan Kepala TK Negeri Pembina Yogyakarta}

Kepemimpinan Kepala TK Negeri Pembina merupakan pemimpin yang visioner karena Ia mampu mencetuskan idea atau gagasan suatu visi yang selanjutnya melalui dialog yang kritis dengan unsur pimpinan yang merumuskan masa depan terhadap keberadaan sekolah sebagai organisasi yang kompleks dan yang dicita-citakan melalui komitmen, terhadap proses sosialisasi, transformasi, implementasi gagasan-gagasan ideal serta mampu melaksanakan peran kepala sekolah sebagai seseorang yang memberikan tanggungjawab dalam memimpin sekolahnya.

Selain itu Kepemimpinan Kepala TK Negeri Pembina termasuk dalam berfikir jangka panjang dimana kepala sekolah bertanggung jawab atas penyelenggaraan pendidikan, administrasi sekolah, pembinaan tenaga kependidikan, dan pendayagunaan serta pemeliharaan sarana dan prasarana. Dengan tersusunnya visi dan misi program kerja, uraian tugas, dan program supervisi sehingga terciptanya pengembangan inovasi-inovasi dalam pembelajaran dan telah berfungsi sebagai TK percontohan. Dalam hal ini juga TK Negeri Pembina dapat menjadi TK percontohan apabila kepala TK, guru, komite TK, dinas pendididikan nasional, dan masyarakat menjalin kerja sama dan memecahkan permasalahan bersama sehingga dapat menentukan strategi dan langkah-langkah yang tepat untuk keberhasilan yang akan datang.

Gaya kepemimpinan yang demikian adalah cara atau teknik seseorang dalam menjalankan suatu kepemimpinan yang berarti pula sebagai norma perilaku yang digunakan seseorang pada saat orang tersebut mencoba mempengaruhi perilaku orang lain seperti yang ia lihat. Dalam hal ini usaha menselaraskan persepsi diantara orang yang akan mempengaruhi perilaku dengan yang akan dipengaruhi menjadi amat penting kedudukannya.

Faktor yang menyebabkan gaya kepemimpinan subjek di TK Negeri Pembina Yogyakarta adalah subjek memberikan semangat yang tinggi dengan mencontohkan moral yang tinggi karena pendidikan yang baik dimulai dari diri kita sendiri, untuk meningkatkan semangat yang tinggi maka sebagai pemimpin harus mencontohkan moral yang tinggi, sehingga dapat menjadi panutan. Subjek mempertahankan orang lain sesuai dengan sifat masing-masing dan memandang orang lain sebagai 
teman kerja yang penting karena penempatan tugas, pekerjaan yang diberikan kepada orang lain sesuai dengan latar belakang kemampuannya, dan memandang bawahan tidak secara struktural antara atasan dengan bawahan, memandang semua orang berkapasitas sama, hanya tugasnya saja yang berbeda. Faktor yang menyebabkan subjek dapat menjalin hubungan yang baik meskipun dengan orang baru, agar orang tersebut merasa nyaman, betah berada di lingkungan itu. Faktor yang menyebabkan subjek memandang konflik sebagai suatu yang wajar, karena konflik dimana saja pasti terjadi sehingga subjek mencari solusi yang baik untuk perbedaan pendapat tersebut agar tidak berkepanjangan.

Cara mengembangkan gaya kepemimpinan subjek di TK Negeri Pembina Yogyakarta adalah memberi semangat dengan memberikan contoh terlebih dahulu kepada bawahan, cara subjek menjalin hubungan meskipun dengan orang baru tetap baik yaitu tidak membedakan dengan pegawai yang lainnya. Cara subjek mempertahankan orang lain apabila orang tersebut memiliki loyalitas dan kinerja yang baik sesuai dengan kemampuan masing-masing sehingga orang tersebut tidak lagi dianggap sebagai bawahan tetapi sebagai teman kerja yang penting. Cara subjek memandang konflik adalah sebagai hal yang wajar dan dapat menyelesaikan perbedaan pendapat dengan mencari solusi yang baik.

\section{Sumber Daya Manusia TK Negeri Pembina Yogyakarta}

Manajemen sumber daya manusia merupakan suatu kegiatan pengelolaan yang meliputi pendayagunaan, pengembangan, penilaian, pemberian balas jasa bagi manusia sebagai individu anggota organisasi maupun lembaga. Manajemen sumber daya manusia juga diartikan sebagai aktifitasaktifitas yang dilaksanakan agar sumber daya manusia dapat didayagunakan secara aktif dan efisien. Pengembangan sumber daya manusia berpijak pada fakta bahwa setiap tenaga kerja sebagai faktor SDM memerlukan pengetahuan, keahlian dan keterampilan yang baik.

TK Negeri Pembina sebagai lembaga formal pendidikan yang memeiliki sumber daya manusia yang baik dan berkompeten dalam penanganan/pengasuhan tumbuh kembang anak usia dini, karena disini Tk Negeri Pembina merupakan TK Negeri percontohan yang harus di akui kualitas output peserta didik. Guru TK Negeri Pembina berjumlah 15 orang yang terdiri dari 10 orang berpendidikan S1 dengan jabatan PNS, 1 orang berpendidikan SPG TK dengan jabatan PNS, 1 orang berpendidikan SPG SD dengan jabatan masih Honda, dan 2 orang berpendidikan D.I dan D. II jabatan masih Honorer, dan 1 orang guru naban.

Lemahnya output yang dihasilkan terhadap pedidikan ilmu pengetahuan semasa pembelajaran dalam tahap perkembangan golden age, membuat banyak pihak terutama orangtua menuntut adanya pengembangan manajemen sumber daya manusia yang memiliki kualitas dan kuantitas secara profesional sebagai SDM. Kegiatan organisasi maupun lembaga yang dilaksanakan menurut fungsifungsi manajemen yaitu planning, organizing, actuating, controlling akan menjamin tercapainya tujuan yang ditetapkan oleh TK Negeri Pembina dan menumbuhkan citra (image) profesionalisme di kalangan masyarakat. Pencapaian tujuan tersebut ditempuh melalui pemanfaatan sumber daya dan sarana serta kerjasama dalam manajemen, karena pada dasarnya manajemen dilakukan oleh, untuk dan dengan manusia.

Faktor manusia dalam manajemen merupakan unsur terpenting sehingga berhasil atau gagalnya suatu manajemen tergantung pada kemampuan untuk mendorong dan menggerakkan SDM yang dimiliki kearah tujuan.Suatu lembaga memerlukan manajemen dalam menjalankan fungsi-fungsi disemua aktifitasnya. Lembaga pendidikan TK Negeri Pembina Yogyakarta merupakan salah satu lembaga pelayanan jasa dalam hal pendidikan dan pembinaan pada anak usia dini dengan latar belakang lingkungan keluarga, sosial, ekonomi dan agama yang berbeda. Oleh sebab itu manajemen dalam pengembangan SDM perlu adanya pondasi mendidik dan mengajar anak usia dini, sehingga SDM yang dihasilkan dapat meningkatkan ilmu pengetahuan, wawasan dan keterampilan tentang ke PAUDan.

Kurikulum adalah upaya untuk mengurus, mengatur, dan mengelola perangkat mata pelajaran yang akan diajarkan pada lembaga pendidikan sebagai pedoman penyelenggaraan kegiatan pembelajaran untuk mencapai tujuan pendidikan tertentu. Sehubungan dengan hal tersebut untuk mengembangkan 
kurikulum kondisi di lapangan menunjukkan adanya variasi kemampuan yang dimiliki oleh sekolah dalam mengembangkan kurikulum tersebut. (Rusman, 2009, p. 1).

Adapun yang menjadi acuan kurikulum TK Negeri Pembina adalah menggunakan Permendiknas nomor 58 tahun 2009 tentang standar pendidikan anak usia dini yang tertuang dalam: ("Permendiknas No 58 Tahun 2009").

Pasal 1

(1) Standar pendidikan anak usia dini meliputi pendidikan formal dan nonformal yang terdiri atas :

a. Standar tingkat pencapaian perkembangan;

b. Standar pendidik dan tenaga kependidikan;

c. Standar isi, proses, dan penilaian; dan

d. Standar sarana dan prasarana, pengelolaan, dan pembiayaan.

(2) Standar pendidikan anak usia dini sebagaimana dimaksud pada ayat (1) tercantum dalam Lampiran Peraturan Menteri ini.

Standar PAUD merupakan bagian integral dari Standar Nasional Pendidikan sebagaimana yang diamanatkan dalam Peraturan Pemerintah Nomor 19 Tahun 2005 tentang Standar Nasional Pendidikan yang dirumuskan dengan mempertimbangkan karakteristik penyelenggaraan PAUD. Standar PAUD terdiri atas empat kelompok yaitu: (1) standar tingkat pencapaian perkembangan; (2) standar pendidik dan tenaga kependidikan; (3) standar isi, proses, dan penilaian; dan (4) standar sarana dan prasarana, pengelolaan, dan pembiayaan.

Standar tingkat pencapaian perkembangan berisi kaidah pertumbuhan dan perkembangan anak usia dini sejak lahir sampai dengan usia enam tahun. Tingkat perkembangan yang dicapai merupakan aktualisasi potensi semua aspek perkembangan yang diharapkan dapat dicapai anak pada setiap tahap perkembangannya, bukan merupakan suatu tingkat pencapaian kecakapan akademik. Standar pendidik (guru, guru pendamping, dan pengasuh) dan tenaga kependidikan memuat kualifikasi dan kompetensi yang dipersyaratkan. Standar isi, proses, dan penilaian meliputi perencanaan, pelaksanaan, dan penilaian program yang dilaksanakan secara terintegrasi/terpadu sesuai dengan kebutuhan anak. Standar sarana dan prasarana, pengelolaan, dan pembiayaan mengatur persyaratan fasilitas, manajemen, dan pembiayaan agar dapat menyelenggarakan PAUD dengan baik.

Pengembangan kurikulum yang terlaksana di TK Negeri Pembina merupakan suatu perwujudan dari pelaksanaan kegiatan pendidikan dalam satuan pendidikan yang berdasarkan atas kurikulum yang berlaku secara nasional dan kurikulum yang disesuaikan dengan keadaan serta kebutuhan lingkungan dan ciri khas satuan pendidikan. Untuk menjamin efektifitas pengembangan kurikulum Kepala Sekolah TK Negeri Pembina selaku pengelola dan bersama guru-guru menjabarkan isi kurikulum secara lebih rinci dan operasional ke dalam program tahunan, catur wulan, dan bulanan dan program mingguan dan rahian (SKM \& SKH) dikembangkan guru sebelum melakukan kegiatan belajar-mengajar.

Adapun beberapa yang menjadikan prinsip yang diperhatikan di TK Negeri Pembina yaitu: (1) tujuan yang dikehendaki harus jelas makin operasional tujuan makin mudah terlihat dan makin tepat program-program yang dikembangkan untuk mencapai tujuan; (2) program itu harus sederhana dan fleksibel; (3) program-program yang disusun dan dikembangkan harus sesuai dengan tujuan yang telah ditetapkan; (4) program yang dikembangkan harus menyeluruh dan harus jelas pencapaiannya; (5) harus ada koordinasi antar komponen pelaksanaan program disekolah. Oleh sebab itu dilakukannya pembagian tugas guru, penyusunan kalender pendidikan dan jadwal pelajaran, pembagian waktu yang digunakan, penempatan pelaksanaan evaluasi belajar, penetapan penilaian, pencatatan kemajuan belajar serta peningkatan perbaikan pengajaran.

\section{SIMPULAN}

Kepemimpinan Kepala TK Negeri Pembina Yogyakarta merupakan kepala TK yang mempunyai karakteristik dan gaya kepemimpinan dengan berkepribadian yang luhur, arif, bijaksana, penuh 
tanggung jawab, dedikasi dan memiliki kebiasaan sendiri yang khas. Kepala TK Negeri Pembina selama keprmimpinannya terdapat empat macam pendekatan studi kepemimpinan,yaitu: (1) pendekatan pengaruh kewibawaan, (2) pendekatan sifat, (3) pendekatan perilaku, dan (4) pendekatan situasional. Fungsi dari kepemimpinannya secara garis besar yaitu mempengaruhi dan menggerakkan orang lain dalam suatu organisasi agar mau melakukan apa yang dikehendaki sebagai seorang pemimpin. Serta memiliki kemampuan dasar berupa technical skills, human skil, dan conceptual skill, pengetahuan dan keterampilan profesional. Dengan terpenuhinya kemampuan tersebut, maka kepala TK Negeri Pembina Yogyakarta dapat memberi keteladanan dalam pelaksanaan tugas, menyusun administrasi dan program sekolah, menentukan anggaran belanja sekolah, dan pembagian pelaksanaan tugas. Gaya kepemimpinan subjek yang termasuk gaya kepemimpinan executive, memberikan semangat yang tinggi dengan mencontohkan moral yang tinggi, menjalin hubungan dengan baik meskipun dengan orang baru tetap mendapat perlakuan yang sama seperti guru-guru yang sudah senior di sekolah tersebut, memandang konflik adalah sebagai hal yang wajar dan dapat menyelesaikan perbedaan pendapat dengan mencari solusi yang baik.

\section{DAFTAR RUJUKAN}

Adnan, M, 2004. Panduan Penelitian Praktis untuk Menyusun Skripsi, Tesis dan Disertasi. Bandung: Alfabeta. Arikunto, S., 2010. Prosedur Penelitian: Suatu Pendekatan Praktek. Jakarta: Rineka Cipta.

Decenzo D.A, Robbins, S.P, 1999. Human Resources Management, 6th ed. John Wiley and Sons, Inc, New York. Moleong, L.J., 2008. Metode Penelitian Kualitatif. Bandung: Remaja Rosdakarya.

Papalia, D.E., Old, W., Shally, 1998. Human Development. New York: Mc Graw Hill. Permendiknas No 58 Tahun 2009 Tentang standar Pendidikan Anak Usia Dini.

Rusman, 2009. Manajemen Kurikulum. Jakarta: Rajawali Pers.

Sugiyono, 2007. Penelitian Kualitatif dan Kuantitatif. Jakarta: Rineka Cipta.

Sutama, 2010. Metode Penelitian Kuantitatif, Kualitatif, PTK, R\&D. Surakarta: Fairuz Media. 